\section{Genes Determining Rind Pattern Inheritance in Watermelon: A Review}

\author{
Gabriele Gusmini and Todd C. Wehner ${ }^{1}$ \\ Department of Horticultural Science, North Carolina State University, Raleigh, \\ NC 27695-7609
}

Additional index words. Citrullus lanatus, Cucurbitaceae, mottled, pencilled, netted, gray

The inheritance of rind pattern and color in watermelon (Citrullus lanatus (Thunb.) Matsum. \& Nakai) has been studied since the 1930s. The most common rind (or skin) colors in watermelon are solid green (dark, medium, and light), striped (narrow, medium, and wide dark green stripes on a light green background), and gray (a light green background with a medium or dark green network of reticulations). Gray is sometimes spelled grey, but the watermelon names have been standardized to the gray spelling.

Gene expression for rind color and pattern does not appear to be consistent in all genetic backgrounds. Furthermore, the inheritance of gray or medium green rind colors has not been published, even though these have been two of the more common rind colors throughout the last century of watermelon breeding.

The inheritance of rind pattern has been described from different perspectives in different publications and the gene names and symbols have been changed over time, thus generating confusion on the proper naming of genes and their trait descriptions. The original type lines used to describe some of these genes are not available any more. Thus, it is not possible to verify the inheritance of those genes, to improve the description of their phenotypes, or to identify alternative type lines through tests of allelism.

Watermelon breeders and geneticists are often confused about the terminology describing basic rind colors and the proper description of some rind patterns that are less common, thus making it difficult to coordinate cooperative studies. This review was aimed at presenting the available information concerning the inheritance of rind color and pattern in watermelon, clarifying the description of uncommon phenotypes, and highlighting questions that remain unanswered.

\section{The Triple-Allelic Series at the $g$ Locus and the Linkage Hypothesis by L.M. Weetman}

In 1937, Weetman proposed that three alleles at a single locus determine the inheritance of striped and solid green (dark and light) rind. The $D$ allele for dark green is dominant to the $d$ allele for light green rind, and the $d^{s}$ allele, which produces stripes, is dominant to $d$ and

Received for publication 12 Apr. 2005. Accepted for publication 19 May 2005.

${ }^{1}$ To whom reprint requests should be addressed; e-mail Todd_Wehner@NCSU.edu. recessive to $D$ (Weetman, 1937). The allelic series was renamed to $G, g^{s}$, and $g$ by Poole in 1944. This hypothesis has been reported in all the gene lists for watermelon (Cucurbit Gene List Committee, 1979; Cucurbit Gene List Committee, 1982; Cucurbit Gene List Committee, 1987; Guner and Wehner, 2003; Henderson, 1991; Henderson, 1992; Rhodes and Dane, 1999; Rhodes and Zhang, 1995; Robinson et al., 1976), using the notation adopted by Poole ( $G$ series). Thus, the original names proposed by Weetman have been replaced. The reason may have been that $g$ was used to name the recessive trait green, rather than $D$ for the dominant trait dark green.

Additional rind colors may derive from combinations of stripes on different shades of green background color (from light to dark), as is the case of the dark green stripes on a dark green background in 'Sugar Baby' or the light yellow spots on a dark green background in 'Moon and Stars'. These examples pose doubts about the behavior of the $g^{s}$ allele, and point to the second hypothesis originally suggested by Weetman in 1937: two gene loci ( $S$ dominant for striping and $D$ dominant for dark green rind) could be controlling the background color and the foreground stripe pattern. The two genes would have been tightly linked in the parents

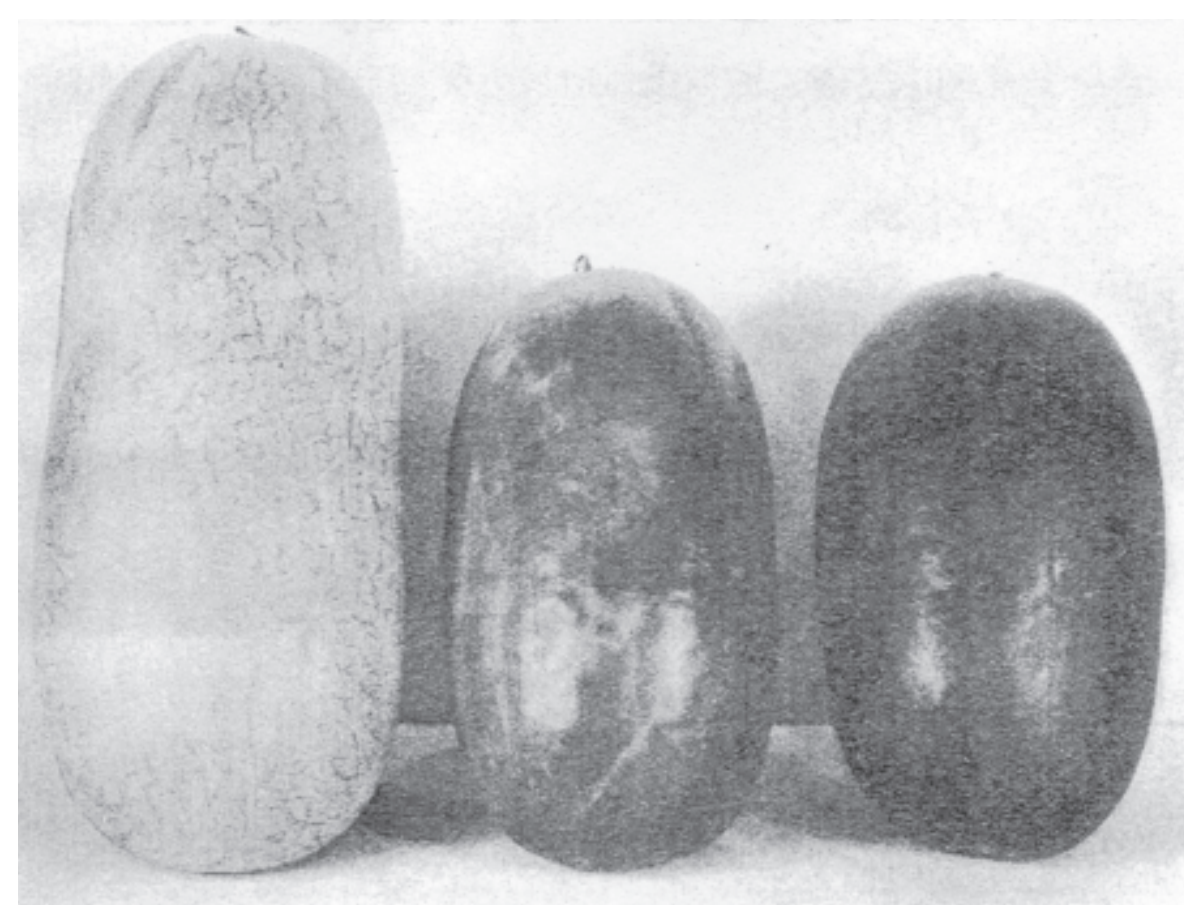

Fig. 1. 'Thurmond Gray' and 'California Klondike' used by Porter in 1937 in the first reported study of the inheritance of dark vs. light green rind colors in watermelon (Porter, 1937). 
more evident in the furrows (longitudinal depressions). The inheritance of gray rind color has not been studied directly and a gene for this trait has never been published.

Porter in 1937 made a cross between 'Thurmond Gray' (gray) and 'California Klondike' (solid dark green) (Fig. 1), but he was interested only in the inheritance of the background color and thus disregarded the netted trait from 'Thurmond Gray'. He described this cultivar as yellowish-green as opposed to the yellowish-white ('Snowball') and the dark-green cultivars ('Angeleno' and 'California Klondike').

Shimotsuma studied the inheritance of striped rind by crossing a striped cultivar with what we would now call a gray cultivar
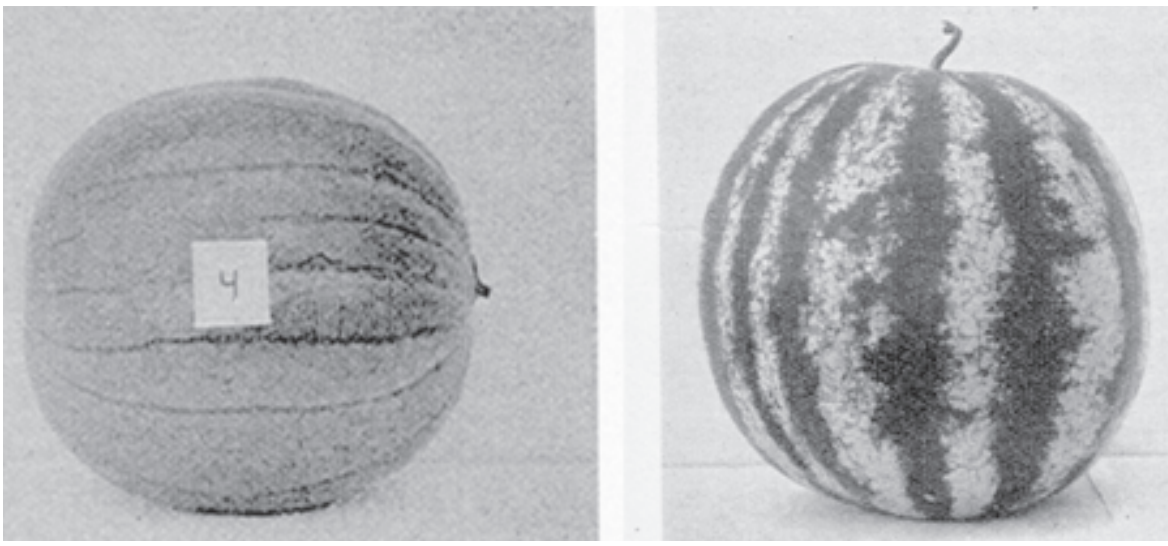

Fig. 2. 'Japan 6' and 'China 23' used by Weetman in 1937 to determine the inheritance of the lined and netted rind patterns ( $p$ and $P$ alleles, respectively) in watermelon (Weetman, 1937).

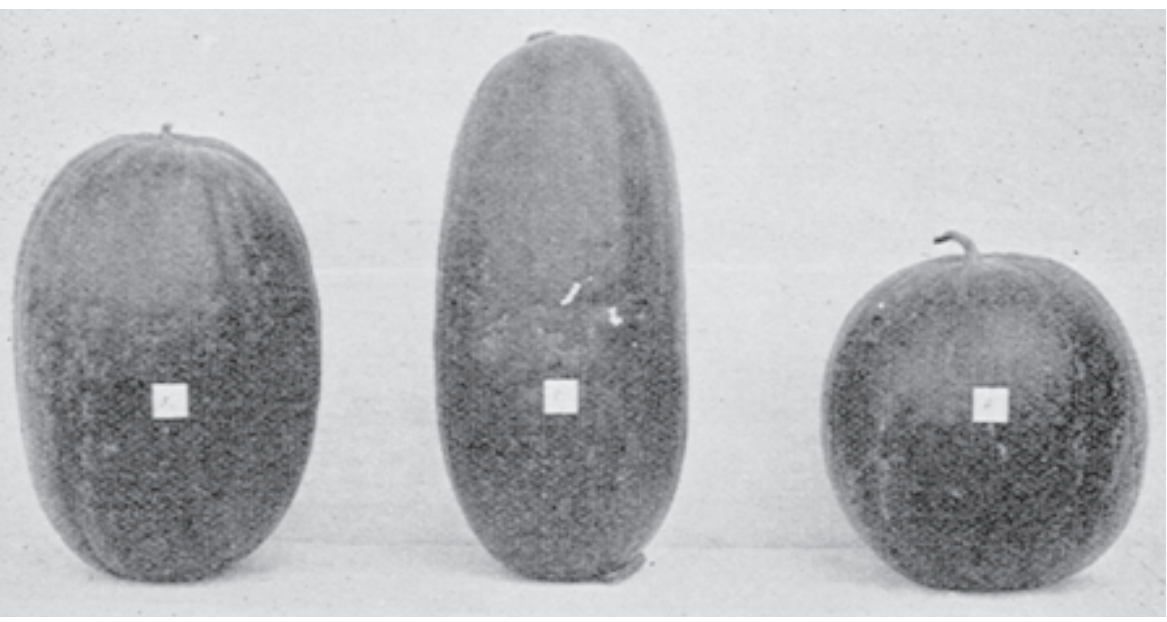

Fig. 3. 'Long Iowa Belle' and 'Round Iowa Belle' used by Weetman in 1937 to determine the inheritance of the mottled rind pattern (a.k.a. Iowa Belle or IB-type) and regulated by the $m$ gene in watermelon (Weetman, 1937).

Table 1. Suggested homozygous genotypes and corresponding phenotypes for the genes known to regulate rind color and pattern in watermelon, along with their type lines.

\begin{tabular}{lccll}
\hline \multicolumn{2}{l}{ Genotype $^{\mathrm{z}}$} & & Phenotype & Type line \\
\hline$G G$ & $(M M)$ & $(P P$ or $p p)$ & Solid dark green & 'Angeleno' \\
$G G$ & $m m$ & $? ?$ & Mottled (dark green) & 'Iowa Belle' (n/a) \\
$g g$ & $(M M)$ & $? ?$ & Solid light green & $? ?$ \\
$(g g)$ & $(M M)$ & $p p$ & Pencilled (light green) \\
$g g$ & $? ?$ & $(P P)$ & Yellowish green (or gray) & 'Japan 6' (n/a) \\
$g^{s} g^{s}$ & $? ?$ & $(P P)$ & Medium-stripe (netted) & 'Thurmond Gray' \\
\hline
\end{tabular}

${ }^{\mathrm{z}}$ Genotypes in parentheses are suggested, based on the available literature, but not demonstrated; ?? indicates that combination has not been investigated, or type line is not known. ticles describing them are difficult to interpret, it would be useful to determine whether $p$ or $m$ were the genes responsible for gray rind. The watermelon gene $p$ for pencilled rind pattern has been reported in the gene lists since 1976 (Robinson et al., 1976). The name penciled first appeared in 1944 to describe inconspicuous lines on self-colored rind of 'Japan 6' (Poole, 1944), but the spelling was changed later to pencilled in the gene lists. The cross 'Japan 6' $\times$ 'China 23' was used by Weetman to study the inheritance of solid light green vs. striped rind, and lined (later renamed pencilled) vs. netted rind(Weetman, 1937). 'Japan 6' had solid light green rind with inconspicuous stripes, usually associated with the furrow (Fig. 2). 'China 23 ' had dark green stripes on a light green background and a network running through the dark stripes (netted type) (Fig. 2). Weetman confirmed his hypothesis of two independent genes regulating the presence of stripes and the lined vs. netted pattern, recovering four phenotypic classes in a 9:3:3:1 ratio (striped, netted : striped, lined : nonstriped, netted : nonstriped, lined) in the $\mathrm{F}_{2}$ generation and in a $1: 1: 1: 1$ ratio in the backcross to the double recessive nonstriped, lined 'Japan 6'. However, Weetman did not name the two genes.

Seeds of the two type lines used by Weetman ('Japan 6' and 'China 23') are not currently available, nor are Porter's data and germplasm, thus making it difficult to confirm the inheritance of the $p$ gene or to identify current inbreds allelic to pencilled and netted rind patterns. In 1944, Poole used the experiment of Weetman to name the single recessive gene $p$ for the lined type. The inheritance of the $p$ gene was measured by Weetman against the netted type in 'China 23' and not a self-colored (or solid green) type as reported by Poole. Previously, Porter reported that studies of rind striping were underway and specifically cited a pencilled pattern in the $\mathrm{F}_{1}$ of the cross 'California Klondike' × 'Golden Honey' (Porter, 1937). The results of these studies have never been published, but they may have been used by Poole to describe the $P$ allele in 1944 as selfcolored skin vs. the $p$ allele for the lined rind. Apparently, with his studies between 1937 and 1944, Poole dismissed Porter's hypothesis of incomplete dominance for the pencilled type, in favor of the single recessive gene $p$. We propose that the $P$ allele produces the netted type, as originally described by Weetman, since the only data published and supporting this model are those by Weetman.

The $m$ gene for mottled rind was first described by Weetman in 'Long Iowa Belle' and 'Round Iowa Belle' (Weetman, 1937). Weetman described the rind as medium-dark green with a distinctive greenish-white mottling, the 'Iowa Belle' (IB) type (Fig. 3). In the cross 'Iowa Belle' $\times$ 'China 23', Weetman observed that the IB type was inherited as a single recessive gene. However, in the cross 'Iowa Belle' × 'Japan 6', he recovered the two parental types (IB and non-IB, respectively) along with an intermediate type (sub-IB), described as inconspicuous mottling. In the backcross to 'Iowa Belle' (the recessive parent for the mottled rind), though, the traits segre- 

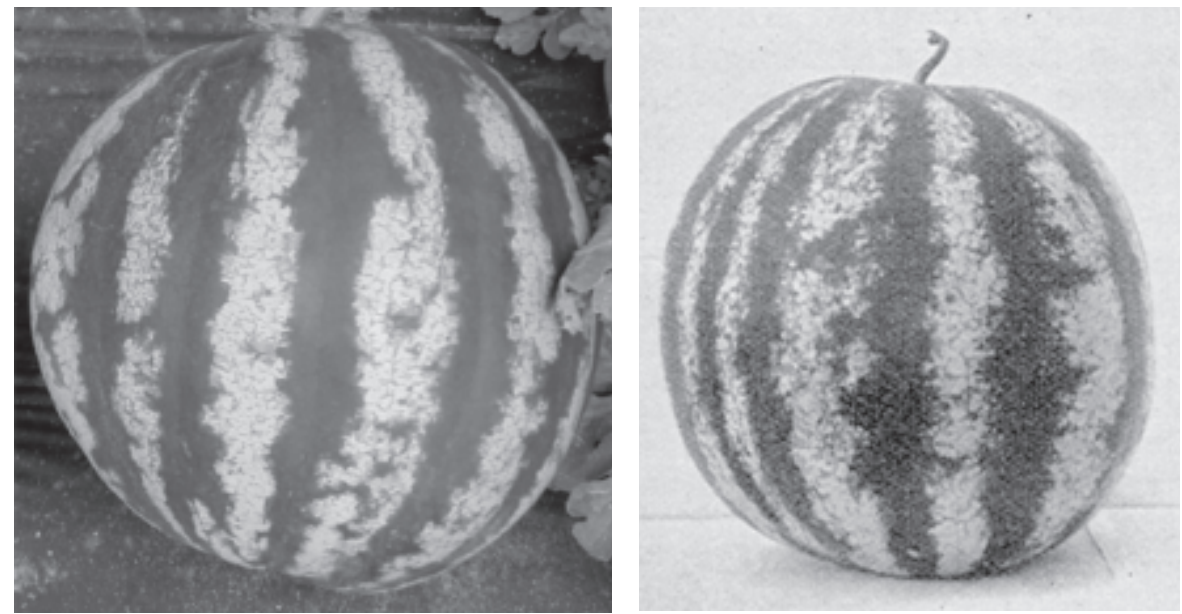

Fig. 4. 'Crimson Sweet' (left) and 'China 23' (right) showing a similar netted phenotype. 'Crimson Sweet', pending verification of the inheritance of the netted phenotype, could be the new type line in substitution of 'China 23' for future genetic studies and breeding work.

gated with a perfect fit to the expected 1:1 ratio. He explained the presence of the intermediate type as determined by interfering genes from 'Japan 6'. There was no other mention of the IB-type until Poole (1944) attributed its inheritance to the $m$ gene from 'Iowa Belle', based on the article by Weetman. 'Iowa Belle' is not currently available and the IB mottling has not been identified in other mutants since the 1937 study by Weetman.

Based on the description of the mottled, or IB, rind type by Weetman, we can exclude any association of the $m$ gene with the gray rind trait. The inheritance of the gray rind may involve, instead, the $P$ allele as described by Weetman in 1937 (netted type) expressed on a light green background (maybe the $g$ or a fourth new allele from Weetman's three allele series at the $g$ locus). Nevertheless, since this hypothesis has not been tested, the $P$ gene should not be considered responsible for the gray rind.

\section{Gene Combinations for Rind Colors}

The homozygous genotypes produced by the genes known to regulate rind color and pattern in watermelon should have the following phenotypes (type-line shown in parentheses): $G G M M P P$ or $G G M M p p=$ solid dark green ('Angeleno'), $G G \mathrm{~mm}=$ mottled dark green ('Iowa Belle', not available), gg $M M=$ solid light green (?), gg $M M p p=$ pencilled ('Japan 6', not available), $g g P P=$ yellowish green or gray ('Thurmond Gray'), and $g^{s} g^{s} P P=$ medium-stripe netted ('Crimson Sweet') (Table 1).

\section{Future Directions for Watermelon Breeders and Geneticists}

Based on the description of the pencilled and netted types reported by Weetman and Poole, and on the images of 'Japan 6' and 'China 23' in the article by Weetman (Fig. 2), we suggest that two inbred cultivars should be identified for the $p$ and $P$ alleles among those currently available as substitute type lines for 'Japan 6' and 'China 23'. The netted type is present on fruit of 'Crimson Sweet', a currently available inbred cultivar (Fig. 4). We suggest that this cultivar be crossed with a nonnetted striped cultivar, to confirm the single-gene segregation for the netted trait. If so, the $P$ allele should be attributed to this new type-line and further verified against $p$, should a replacement for 'Japan 6' be found.

A new type-line for the mottled rind type could be identified by tracing the pedigree of 'Iowa Belle'. The cultivar was released in 1932 by Porter, having 'Conqueror' and another unknown line as parents (Wehner, 2002). The unknown parent is suspected to be 'Kleckley Sweet', but this cultivar does not have mottled rind. 'Conqueror' is not presently available, but its pedigree included citron (C. lanatus var. citroides) as the source of Fusarium wilt resistance. It is possible that the mottled type was already present in 'Conqueror' from the citron parent. Evaluation of the citrons available in the USDA-ARS watermelon germplasm collection may allow the identification of a new type-line carrying a gene for the mottled rind type. Finally, several heirloom and modern cultivars had 'Iowa Belle' in their pedigree, including 'Charleston Gray', 'Congo', 'Fairfax', and 'Garrisonian', but none had mottled rind.

Further research is needed on the inheritance of the gray rind color in watermelon, and the effect of the $G$ allele on the light green background of gray cultivars. The inheritance of fruit netting and background color in gray watermelons should be studied, and a linkage hypothesis of two genes for these traits should be tested.

The study of the inheritance of striped rind should expand the original model by Weetman to include different stripe width and different shades of the background green color. Narrow-, medium-, and wide-striped, and dark, medium, and light green cultivars should be crossed in a half-diallel, and $\mathrm{F}_{1}, \mathrm{~F}_{2}$, and $\mathrm{BC}_{1}$ generations should be developed. Should a model be established, then it should be verified against the inheritance of gray color to develop a model for rind color in watermelon.

To avoid the loss of type lines for new genes discovered in future research, seeds of the mutants used in inheritance studies should be sent to the watermelon gene curators for the Cucurbit Genetics Cooperative (T.C. Wehner and S.R. King), as well as to the National Center for Genetic Resources Preservation (USDA-ARS, Fort Collins, Colo.).

\section{Literature Cited}

Cucurbit Gene List Committee. 1979. New genes for the Cucurbitaceae. Cucurbit Genet. Coop. Rpt. 2:49-53.

Cucurbit Gene List Committee. 1982. Update of cucurbit gene list and nomenclature rules. Cucurbit Genet. Coop. Rpt. 5:62-66.

Cucurbit Gene List Committee. 1987. Gene list for watermelon. Cucurbit Genet. Coop. Rpt. 10:106-110.

Guner, N. and T.C. Wehner. 2003. Gene list for watermelon. Cucurbit Genet. Coop. Rpt. 26:76-92.

Henderson, W.R. 1991. Gene list for watermelon. Cucurbit Genet. Coop. Rpt. 14:129-138.

Henderson, W.R. 1992. Corrigenda to 1991 watermelon gene list (CGC 14:129-137). Cucurbit Genet. Coop. Rpt. 15: 110.

Poole, C.F. 1944. Genetics of cultivated cucurbits. Journal of Heredity. 35:122-128.

Porter, D.R. 1937. Inheritance of certain fruit and seed characters in watermelons. Hilgardia 10:489-509.

Rhodes, B. and F. Dane. 1999. Gene list for watermelon. Cucurbit Genet. Coop. Rpt. 22:61-77.

Rhodes, B. and X. Zhang. 1995. Gene list for watermelon. Cucurbit Genet. Coop. Rpt. 18:69-84.

Robinson, R.W., H.M. Munger, T.W. Whitaker, and G.W. Bohn. 1976. Genes of the Cucurbitaceae. HortScience 11:554-568.

Shimotsuma, M. 1963. Cytogenetical studies in the genus Citrullus. VII. Inheritance of several characters in watermelon. Jpn. J. Breed. 13:235-240.

Weetman, L.M. 1937. Inheritance and correlation of shape, size and color in the watermelon, Citrullus vulgaris Schrad. Iowa Agr. Expt. Sta. Annu. Bul. 228:224-256.

Wehner, T.C. 2002. Vegetable cultivar descriptions for North America. List 26-2002. HortScience $37: 15-78$ 